
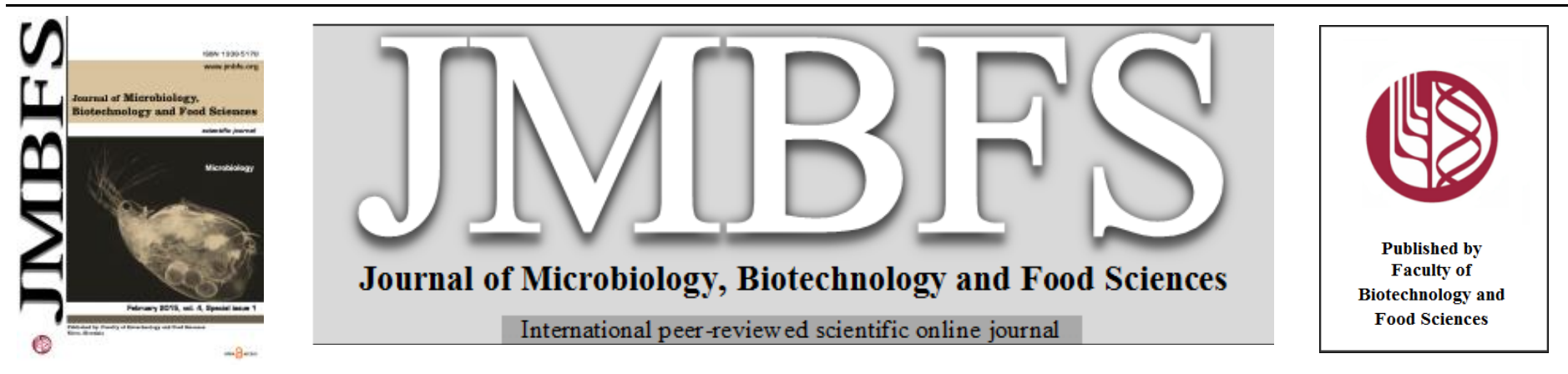

\title{
BIOGENIC AMINES CONTENT IN DIFFERENT WINE SAMPLES
}

\section{Attila Kántor $^{1 *}$, Miroslava Kačániovál ${ }^{\text {, Vendula Pachlová }}{ }^{2}$}

\author{
Address(es): Mgr. Attila Kántor, \\ ${ }^{1}$ Department of Microbiology, Faculty of Biotechnology and Food Sciences, Slovak University of Agriculture in Nitra, Trieda Andreja Hlinku 2, 94976 Nitra, \\ Slovakia.
}

${ }^{2}$ Department of Food Technology, Faculty of Technology, Tomas Bata University in Zlin, nám. T. G. Masaryka 5555, 76001 Zlín, Czech Republic.

*Corresponding author: kantor.spu@gmail.com

doi: 10.15414/jmbfs.2015.4.special1.37-40

ARTICLE INFO

Received 11. 11.2014

Revised 17. 12. 2014

Accepted 23. 12. 2014

Published 3. 2. 2015

Regular article

OPEN $\partial$ ACCESS

\section{ABSTRACT}

Twenty-five samples of different Slovak wines before and after filtration were analysed in order to determine the content of eight biogenic amines (tryptamine, phenylalanine, putrescine, cadaverine, histamine, tyramine, spermidine and spermine). The method involves extraction of biogenic amines from wine samples with used dansyl chloride. Ultra-high performance liquid chromatography (UHPLC) was used for determination of biogenic amines equipped with a Rapid Resolution High Definition (RRHD), DAD detectors and Extend-C18 LC column (50 $\mathrm{mm} \times 3.0 \mathrm{~mm}$ ID, $1.8 \mu \mathrm{m}$ particle size). In this study the highest level of biogenic amine in all wine samples represent tryptamine (TRM) with the highest content $170.9 \pm 5.3 \mathrm{mg} / \mathrm{L}$ in Pinot Blanc wine. Phenylalanine (PHE) cadaverine (CAD), histamine (HIS) and spermidine (SPD) were not detected in all wines; mainly SPD was not detected in 16 wines, HIS not detected in 14 wines, PHE and CAD not detected in 2 wines. Tyramine (TYR), spermine (SPN) and putrescine (PUT) were detected in all wines, but PUT and SPN in very low concentration. The worst wine samples with high biogenic amine content were Saint Laurent (BF), Pinot Blanc (S) and Pinot Noir (AF).

Keywords: Wine, filtration, biogenic amines, UHPLC

\section{INTRODUCTION}

Biogenic amines (BA) are an important group of organic nitrogenous bases (Santos, 1996). They are naturally synthesized in animals, plants and microorganisms. Biogenic amines in foods and feeds are formed mostly by bacterial decarboxylation of free amino acids (Shakila et al., 2001) and its presence is a typical indicator of spoilage (Anli and Bayram, 2008; Shalaby, 1996).

These amines are formed along the vinification process, mainly during alcoholic (Caruso et al., 2002) and malolactic fermentations (Arena and de Nadra, 2001; Landete et al., 2007).

Yeasts responsible of alcoholic fermentation produce some biogenic amines like putrescine, cadaverine and phenylethylamine (Marcobal et al., 2006), but in much lower amounts compared to malolactic fermentation (MLF). This fermentative step is catalysed by lactic acid bacteria, in most cases by Oenococcus oeni species (Ancin-Azpilicueta et al., 2008).

BA are produced in wines by diverse lactic acid bacteria (LAB), but only by strains carrying specific metabolic pathways that convert precursor amino acids into BA (Arena and Manca de Nadra 2001; Lonvaud-Funel 2001). For a long time BA formation in wine has been mainly associated with non-oenococcal strains, such as spoilage Pediococcus and Lactobacillus strains, whose presence is related with high $\mathrm{pH}$ wine conditions (Marcobal $\boldsymbol{e t}$ al., 2004). MLF of wine generally starts spontaneously when the population of indigenous $\mathrm{LAB}$ reaches a sufficient level. When the conditions of wine are favourable to the development of BA-producing LAB, spontaneous MLF can lead to the accumulation of significant amounts of BA (Lonvaud-Funel 2001).

During MLF, lactic acid bacteria converted L-malic acid to L-lactic acid mainly via malate decarboxylase (malolactic enzyme), this biotransformation produces a medium deacidify, enhance organoleptic properties and improve microbiological stability (Capozzi et al., 2010; Versari et al., 1999). For that reasons, MLF can be considered a critical vinification stage for red wines production. Unfortunately, it is during this fermentation when the highest amount of biogenic amines is produced (Ancin-Azpilicueta et al., 2008; Anli and Bayram, 2009). Marques et al. (2008) have reported concentration near to $30 \mathrm{mg} / \mathrm{L}$.

Although biogenic amines content in wines depends on several factors such as amino acids content in grapes and must (Sass-Kiss et al., 2000), maceration (Martin-Alvarez et al., 2006), vintage (Martin-Alvarez et al., 2006), $\mathrm{SO}_{2}$ concentration (Vidal-Carou et al., 1990), acidity (Souza et al., 2005), grape variety (Marques et al., 2008), amino acids concentration (Herbert $\boldsymbol{e t}$ al., 2005, 2006), vinification conditions ( $\mathrm{pH}$, temperature, etc.) (Ancin-Azpilicueta et al., 2008), lees content and bacterial decarboxylase capacity (Landete $\boldsymbol{e t}$ al., 2005), it is generally accepted that the biogenic amines formation is highly dependent on the nature of lactic acid bacteria responsible of malolactic fermentation (aminogenic capacity) (Ancin-Azpilicueta et al., 2008; Martin-Alvarez et al., 2006). Biogenic amines content also depends on the type of wine. It is well known that red wines present higher biogenic amines concentrations than white ones.

The aim of this study was to determine eight biogenic amines in different wine samples collected before and after filtration. For microbial analysis we used plate dilution method on different agar mediums and for determination of biogenic amines in wine samples used ultra-high performance liquid chromatography (UHPLC).

\section{MATERIAL AND METHODS}

Wine samples

A total 25 wine samples were collected from small winery nearby Nižné Valice village. We collected 10 red wines, 10 white wines before and after microfiltration and 5 special wines before filtration and bottling. Red wines before and after filtration includes varieties Blaufränkisch, Cabernet Sauvignon, Pinot Noir, Saint Laurent and Blauer Portugieser. White wines before and after filtration includes varieties Grüner Veltliner, Pinot Gris, Chardonnay, Müller Thurgau and Welschriesling. The 5 special wine varieties were Chardonnay, Pinot Blanc, Pálava, Cabernet Sauvignon and Rimava. These special wine samples were collected from stainless steel wine tanks (max. volume $1000 \mathrm{~L}$ ) (special wines), next wines before microfiltration (BF) collected from giant storage tanks (wine tanks with max. volume $35000 \mathrm{~L}$ ). Samples from giant tank were collected by pouring into the PET bottles with faucet. Wines after microfiltration (AF) were collected from bottled wines. We used 40x40 cm stainless steel plate filter with $0.5 \mu \mathrm{m}$ porosity filter cartridges. Wine samples collected from bottled wine poured into $200 \mathrm{~mL}$ sterile PET bottles, closed and immediately storage at $6-8^{\circ} \mathrm{C}$ to first analysis. 


\section{Microbial analysis}

For microbiological analysis the wine samples were processed first. The total counts of bacteria (TBC), number of acetic acid bacteria (A), lactic acid bacteria (L) and yeast (Y) were assessed. Plate diluting method was applied for quantitative CFU (Colony Forming Units) counts determination of respective groups of microorganisms in $1 \mathrm{~mL}$ of wine. Petri dishes of gelatinous nutritive substrate were inoculated with $100 \mu \mathrm{L}$ of wine samples on the surface of the solid agar in three replications. Homogenized samples of wine were prepared in advance by sequential diluting based on decimal dilution system application. For microorganism cultivation 4 different agar medium were used, to segregate individual microorganism groups. For identification of TCB we used Tryptic Glucose Yeast agar (TGYA) (Biolife, Italy) and incubated the samples at $30^{\circ} \mathrm{C}$ for 48-72h aerobically. Acetic acid bacteria cultivated on Acetobacter agar with glucose (AA) (HiMedia, India) and incubated at $28^{\circ} \mathrm{C}$ for $48 \mathrm{~h}$ aerobically. Lactic acid bacteria cultivated on MRS (HiMedia, India), incubated at $37^{\circ} \mathrm{C}$ for $72 \mathrm{~h}$ in microaerophilic condition. Finally yeast cultivated on Sabouraud agar with chloramphenicol (SCHA) (HiMedia, India) and incubated at $25^{\circ} \mathrm{C}$ for 5 days.

\section{Derivatization and Chromatography}

Production of 8 biogenic amines tryptamine (TRM), phenylalanine (PHE), putrescine (PUT), cadaverine (CAD), histamine (HIS), tyramine (TYR), spermidine (SPD) and spermine (SPN) were monitored by ultra-high performance liquid chromatography (UHPLC). At the beginning $650 \mu \mathrm{L}$ of wine samples in five replications were diluted with perchloric acid $(c=1.2 \mathrm{~mol} / \mathrm{L})$ in proportion 1:1 and storaged in the freezer for next analysis. The wine samples were dansylated by dansyl chlorid according by Dadáková et al. (2009). One millitre of acidic extract was spiked with $100 \mu$ l of internal standard solution (1.7heptanediamine, $400 \mathrm{mg} / \mathrm{L}$ ) and mixed in a plastic test tube with $1.5 \mathrm{~mL}$ of carbonate buffer $\mathrm{pH} 11$. After briefly vortexing, $2 \mathrm{~mL}$ of dansyl chloride solution were added (dansyl chloride in acetone $5 \mathrm{mg} / \mathrm{mL}$ ). The test tube was then shaken at room temperature for $20 \mathrm{~h}$ in darkness. Subsequently $200 \mu \mathrm{l}$ of proline solution $(100 \mathrm{mg} / \mathrm{mL})$ were added and the sample was shaken for additional $1 \mathrm{~h}$. Then follows an extraction with $3 \mathrm{~mL}$ of heptane. One milliliter of extract was dried at $60^{\circ} \mathrm{C}$ under a stream of nitrogen. The dry residue was dissolved in $1.5 \mathrm{~mL}$ of acetonitrile. Samples were filtered through membrane glass fiber filters $(0.22 \mu \mathrm{m})$ prior to analysis (Dadáková et al., 2009)

The UPLC separation was carried out on an Agilent Zorbax Extend-C18 LC column (50 mm x $3.0 \mathrm{~mm} \mathrm{ID,} 1.8 \mu \mathrm{m}$ particle size), equipped with a Rapid Resolution High Definition (RRHD) (Agilent technologies, USA) Chromatographic separation was carried out using a gradient elution of (A) acetonitrile $\left(10 \% \mathrm{v} / \mathrm{v}\right.$ in $\left.\mathrm{H}_{2} \mathrm{O}\right)$, (B) acetonitrile $\left(100 \% \mathrm{v} / \mathrm{v}\right.$ in $\left.\mathrm{H}_{2} \mathrm{O}\right)$. Linear concentration change was performed in all cases. The flow rate was kept at 0.45 $\mathrm{mL} / \mathrm{min}$, column temperature at $30^{\circ} \mathrm{C}$, injection $5 \mu 1$, the detection wavelength at $254 \mathrm{~nm}$ with DAD detectors.

\section{RESULTS AND DISCUSSION}

Biogenic amines content in food or drinks represent a health risk for sensitive individuals, especially when their effect is potentiated by other substances. Most toxic are histamine and tyramine (Chen $\boldsymbol{e t}$ al., 2008). Biogenic amines content also depends on the type of wine. It is well known that red wines present higher biogenic amines concentrations than white ones. This may occur because red wine production includes: maceration step with grape skin, which not only increase the polyphenols cession but also others compounds like amino acids (Martin-Alvarez et al., 2006), higher fermentation temperature and application of MLF, which is not commonly applied for white wines production or it has a shorter duration (Ancin-Azpilicueta et al., 2008; Lonvaud-Funel, 2001) Several authors have reported the biogenic amines in wines produced with different grape varieties as well as various valleys and countries. A wide range is observed, starting from not-detected levels up to $130 \mathrm{mg} / \mathrm{L}$ (Ancin-Azpilicueta et al., 2008). The amount and type of amine formed is influenced by the food composition, microbial flora and by several parameters, which promote bacterial growth during storage such as temperature, ripening and packaging (Halász, et al., 1994; Kř́žzek et al., 2004). Biogenic amines content in different wine samples before and after microfiltration were shows in Table 1.

Table 1 Biogenic amine content in wine samples

\begin{tabular}{|c|c|c|c|c|c|c|c|c|}
\hline Wine sample & Tryptamine & Phenylalanine & Putrescine & Cadaverine & Histamine & Tyramine & Spermidine & Spermine \\
\hline Blaufränkisch BF & $86.5 \pm 16.6$ & $2.5 \pm 2.0$ & $12.1 \pm 2.3$ & $1.7 \pm 1.2$ & $0.4 \pm 0.07$ & $3.8 \pm 1.4$ & ND & $3.6 \pm 1.4$ \\
\hline Blaufränkisch AF & $75.1 \pm 30.5$ & $1.2 \pm 0.9$ & $7.7 \pm 4.5$ & $1.1 \pm 0.7$ & $1.3 \pm 0.2$ & $7.8 \pm 1.7$ & ND & $3.6 \pm 1.3$ \\
\hline Cabernet Sauvignon BF & $34.9 \pm 3.0$ & $2.5 \pm 0.1$ & $9.2 \pm 0.6$ & $0.1 \pm 0.01$ & $4.0 \pm 0.1$ & $9.2 \pm 3.9$ & $1.0 \pm 0.2$ & $2.4 \pm 0.9$ \\
\hline Cabernet Sauvignon AF & $31.9 \pm 5.5$ & $1.6 \pm 1.3$ & $11.1 \pm 0.8$ & $0.1 \pm 0.04$ & $5.3 \pm 0.5$ & $12.9 \pm 2.6$ & $1.4 \pm 0.6$ & $1.1 \pm 0.4$ \\
\hline Pinot Noir BF & $71.8 \pm 18.2$ & $3.6 \pm 1.6$ & $8.9 \pm 1.6$ & $1.0 \pm 0.2$ & $2.2 \pm 0.1$ & $6.2 \pm 1.6$ & $0.5 \pm 0.4$ & $3.3 \pm 1.2$ \\
\hline Pinot Noir AF & $85.9 \pm 5.3$ & $5.6 \pm 2.4$ & $12.8 \pm 0.9$ & $0.8 \pm 0.6$ & $4.0 \pm 0.3$ & $6.8 \pm 1.7$ & $0.7 \pm 0.1$ & $1.8 \pm 0.2$ \\
\hline Saint Laurent BF & $40.6 \pm 8.8$ & $3.9 \pm 5.2$ & $9.8 \pm 3.1$ & $2.9 \pm 6.1$ & $5.4 \pm 0.9$ & $12.9 \pm 8.9$ & $13.9 \pm 0.4$ & $2.7 \pm 1.5$ \\
\hline Saint Laurent AF & $89.4 \pm 64.2$ & $2.3 \pm 1.6$ & $8.9 \pm 3.1$ & $1.3 \pm 0.9$ & ND & $4.2 \pm 1.5$ & ND & $3.1 \pm 2.1$ \\
\hline Blauer Portugieser BF & $69.7 \pm 2.8$ & $5.0 \pm 0.3$ & $7.6 \pm 0.5$ & $0.6 \pm 0.05$ & $1.9 \pm 0.07$ & $5.7 \pm 6.1$ & ND & $2.2 \pm 0.3$ \\
\hline Blauer Portugieser AF & $120.6 \pm 7.6$ & $3.4 \pm 1.9$ & $10.0 \pm 3.1$ & ND & ND & $3.6 \pm 0.7$ & ND & $3.1 \pm 0.6$ \\
\hline Grüner Veltliner BF & $43.9 \pm 1.5$ & $0.3 \pm 0.4$ & $4.3 \pm 0.4$ & $0.3 \pm 0.1$ & ND & $2.3 \pm 0.5$ & ND & $1.5 \pm 0.2$ \\
\hline Grüner Veltliner AF & $49.0 \pm 4.5$ & $0.6 \pm 0.4$ & $5.0 \pm 1.5$ & $0.4 \pm 0.1$ & ND & $7.4 \pm 5.6$ & ND & $1.8 \pm 0.2$ \\
\hline Pinot Gris BF & $41.3 \pm 6.4$ & $1.6 \pm 0.6$ & $4.5 \pm 1.0$ & $0.3 \pm 0.08$ & ND & $3.8 \pm 2.3$ & ND & $1.7 \pm 0.3$ \\
\hline Pinot Gris AF & $45.5 \pm 6.3$ & $2.6 \pm 0.6$ & $4.7 \pm 1.0$ & $0.5 \pm 0.3$ & ND & $9.1 \pm 5.8$ & ND & $1.3 \pm 0.1$ \\
\hline Chardonnay BF & $59.7 \pm 26.6$ & $2.4 \pm 0.8$ & $6.4 \pm 2.9$ & $0.6 \pm 0.1$ & ND & $7.3 \pm 4.0$ & ND & $1.5 \pm 0.4$ \\
\hline Chardonnay AF & $51.7 \pm 10.3$ & $1.2 \pm 0.5$ & $5.9 \pm 1.8$ & ND & ND & $5.1 \pm 2.4$ & ND & $1.6 \pm 0.2$ \\
\hline Müller Thurgau BF & $47.5 \pm 7.8$ & $1.1 \pm 0.6$ & $4.8 \pm 1.2$ & $0.3 \pm 0.1$ & ND & $3.1 \pm 0.9$ & ND & $1.6 \pm 0.4$ \\
\hline Müller Thurgau AF & $41.9 \pm 7.1$ & $1.7 \pm 1.3$ & $6.1 \pm 0.5$ & $0.1 \pm 0.06$ & $2.7 \pm 0.08$ & $7.6 \pm 5.6$ & ND & $1.2 \pm 0.4$ \\
\hline Welschriesling BF & $92.2 \pm 32.4$ & $4.5 \pm 3.4$ & $3.1 \pm 1.8$ & $0.4 \pm 0.02$ & ND & $5.0 \pm 1.3$ & ND & $1.3 \pm 0.4$ \\
\hline Welschriesling AF & $91.9 \pm 5.1$ & $2.1 \pm 0.9$ & $9.2 \pm 0.6$ & $0.5 \pm 0.06$ & $2.2 \pm 0.2$ & $4.9 \pm 1.2$ & ND & $1.8 \pm 0.7$ \\
\hline Pinot Blanc S & $170.9 \pm 5.3$ & ND & $3.0 \pm 0.9$ & $3.7 \pm 2.3$ & ND & $4.1 \pm 0.8$ & ND & $2.8 \pm 0.8$ \\
\hline Chardonnay S & $44.6 \pm 2.9$ & ND & $1.5 \pm 1.1$ & $0.2 \pm 0.2$ & ND & $6.6 \pm 11.6$ & ND & $2.3 \pm 0.6$ \\
\hline Pálava S & $38.0 \pm 2.3$ & $0.1 \pm 0.09$ & $1.5 \pm 0.3$ & $0.1 \pm 0.03$ & ND & $5.0 \pm 1.5$ & ND & $1.8 \pm 0.3$ \\
\hline Cabernet Sauvignon $\mathrm{S}$ & $40.7 \pm 3.2$ & $0.6 \pm 1.0$ & $4.8 \pm 0.4$ & $0.8 \pm 1.0$ & $0.1 \pm 0.05$ & $2.3 \pm 0.9$ & $0.3 \pm 0.1$ & $1.6 \pm 0.1$ \\
\hline Rimava $S$ & $42.7 \pm 4.4$ & $0.1 \pm 0.04$ & $3.6 \pm 3.1$ & $0.3 \pm 0.3$ & ND & $2.3 \pm 1.5$ & $1.0 \pm 0.4$ & $2.3 \pm 0.1$ \\
\hline
\end{tabular}

BF- before filtration, AF - after filtration, $\mathbf{S}$ - special wine, ND - not detected, Unit - $\mathbf{m g} / \mathbf{L}$

Highest level of biogenic amine in all wine samples represent tryptamine (TRM) with the highest content $170.9 \pm 5.3 \mathrm{mg} / \mathrm{L}$ in Pinot Blanc wine. Generally TRM content in wine samples varied from $31.9 \pm 5.5 \mathrm{mg} / \mathrm{L}$ to $170.9 \pm 5.3 \mathrm{mg} / \mathrm{L}$. In Pinot Blanc wine not detected phenylalanine (PHE) and spermidine (SPD). PHE content detected in 23 wine samples in small amount varied from $0.1 \pm 0.04 \mathrm{mg} / \mathrm{L}$ to $5.6 \pm 2.4 \mathrm{mg} / \mathrm{L}$ in wine Pinot Noir (AF). Putrescine (PUT) detected in all wines and the highest level was in red wine Pinot Noir (AF) $12.8 \pm 0.9 \mathrm{mg} / \mathrm{L}$. Cadaverine (CAD), histamine (HIS) and spermidine (SPD) were not detected in all wines, mainly SPD was not detected in 16 wine samples, but the highest content of this biogenic amine was detected in Saint Laurent $(\mathrm{BF})$ red wine $(13.9 \pm 0.4 \mathrm{mg} / \mathrm{L})$. The most toxic biogenic amine histamine was not detected in 14 wines, but the highest detected level of this biogenic amine was recorded in Saint Laurent (BF) wine, only $5.4 \pm 0.9 \mathrm{mg} / \mathrm{L}$. CAD and PHE were not detected in two wine samples, for CAD (Blauer Portugieser AF, and Chardonnay AF) and for PHE (Pinot Blanc $\mathrm{S}$ and Chardonnay S) wines. Tyramine (TYR) and spermine (SPN) were detected in all wine, but TYR in higher concentrations than SPN. The TYR content in wines varied from $2.3 \pm 0.5 \mathrm{mg} / \mathrm{L}$ to $12.9 \pm 2.6 \mathrm{mg} / \mathrm{L}$, and the highest concentration was detected against in wine Saint Laurent (BF). SPN content in wines varied 
from $1.1 \pm 0.4 \mathrm{mg} / \mathrm{L}$ to $3.6 \pm 1.4 \mathrm{mg} / \mathrm{L}$. The same highest concentration was detected in wines Blaufränkisch after and before filtration (AF, BF).

The order of analysed biogenic amines from the highest to the lowest quantities for all wines was determined as follows: tryptamine $>$ cadaverine $>$ tyramine $>$ phenylalanine $>$ spermidine $>$ spermine $>$ histamine $>$ putrescine. The highest concentration of TRM was detected in red wines after filtration (AF), red wines before filtration $(\mathrm{BF})$ and special wines $(\mathrm{S})$. Average value of TRM from five red wines after filtration was $80.57 \mathrm{mg} / \mathrm{L}$, red wines $(\mathrm{BF})$ was $60.68 \mathrm{mg} / \mathrm{L}$ and special wines was $67.37 \mathrm{mg} / \mathrm{L}$. Average value of CAD content was in the highest level once again in red wine samples (AF) $10.11 \mathrm{mg} / \mathrm{L}, 9.52 \mathrm{mg} / \mathrm{L}$ in red wines (BF). Tyramine content represents $7.55 \mathrm{mg} / \mathrm{L}$ in red wines $(\mathrm{BF})$ and $7.07 \mathrm{mg} / \mathrm{L}$ in red wines $(\mathrm{AF})$. A smaller concentration of biogenic amines was detected in white wines except TRM concentration in white wines AF, BF and in special wines. We detected putrescine, histamine, spermine and spermidine in very small concentration in white wines. The lowest detected biogenic amines in wine samples was PUT. Figure 1 shows results from average values of eight biogenic amines in five groups of wines.

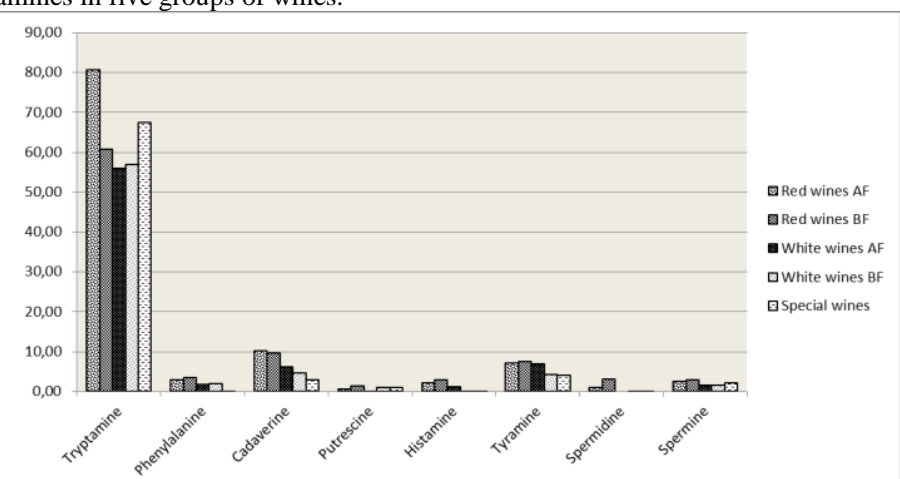

Figure 1 Average value of biogenic amines in different groups of wines in $\mathrm{mg} / \mathrm{L}$ BA are present in fermented products (e.g. cheese $5-4500 \mathrm{mg} / \mathrm{kg}$, wine $5-130$ $\mathrm{mg} / \mathrm{L}$, beer $2.8-13 \mathrm{mg} / \mathrm{L}$, sauerkraut $110-300 \mathrm{mg} / \mathrm{kg}$ ) and in improperly kept food (such as fish 2400-5000 mg/kg, beef liver about $340 \mathrm{mg} / \mathrm{kg}$, prepared meats 10 $700 \mathrm{mg} / \mathrm{kg}$ ) (Křížek et al., 1998).

Red wines contained higher amounts of biogenic amines than white wines in this study. I confirmed in my study, that white wines, which are generally more acidic, contains lower biogenic amine concentrations than red wines (Loukou et al., 2003; Lonvaud-Funel, 2001). Surprisingly, tryptamine was the mos abundant biogenic amine in the analyzed samples. Literature data confirm, that: histamine, tyramine, putrescine, cadaverine, spermine, spermidine, isophenylamine, and $\beta$-phenylethylamine were detected in wines as a predominant biogenic amines (especially in red wines), while tryptamine was found only sporadically (Ancin-Azpilicueta et al., 2008; Konakovsky et al. 2011; Peña-Gallego at al., 2012). Mean levels of histamine were at $3.63 \mathrm{mg} / \mathrm{L}$ for French wines, $2.19 \mathrm{mg} / \mathrm{L}$ for Italian wines, and $5.02 \mathrm{mg} / \mathrm{L}$ for Spanish wines (Marcobal et al., 2005).

In this study the highest level of histamine was detected in Saint Laurent red wine (BF) $5.4 \pm 0.9 \mathrm{mg} / \mathrm{L}$ and $2.7 \pm 0.08 \mathrm{mg} / \mathrm{L}$ in Müller Thurgau white wine (AF). In the special wines group histamine content detected only in red wine Cabernet Sauvignon in content $0.1 \pm 0.05 \mathrm{mg} / \mathrm{L}$. Histamine not detected in 14 wine samples Also SPD was not detected in 16 wine samples, and the highest level of this biogenic amine was detected in wine Saint Laurent (BF) in amount $13.9 \pm 0.4$ $\mathrm{mg} / \mathrm{L}$. It should be noted, that TRM, CAD and TYR were detected in red wines, probably due to the malolactic fermentation, resulting in a high content of these amines, but TRM concentration was very high also in white wines. HIS, PUT and SPD were detected in very small content. Biogenic amines may induce toxicological risks and health troubles (Halász et al., 1999).

The most frequent foodborne intoxications caused by histamine (Bardócz, 1995) An intake of $5-10 \mathrm{mg}$ of histamine can be considered as defecting to some sensitive people, $10 \mathrm{mg}$ is considered as tolerable limit, $100 \mathrm{mg}$ induce a medium toxicity and $1000 \mathrm{mg}$ is highly toxic (Lehane $\boldsymbol{e t}$ al., 2000). In study Buňka et al (2012), was recorded very high content of three biogenic amines (PUT, TYR and HIS) during 300-day winemaking process.

It is known that biogenic amines in wine can be formed from their respective amino acid precursors by various microorganisms present in wine, at any stage of production, ageing or storage. Usually, the content of biogenic amines increases during winemaking and maturation (Piasta et al., 2014).

\section{CONCLUSION}

Biogenic amines are natural compounds of many foods and drinks. They are formed mainly by decarboxylation of amino acids. There are three possible origins for BA in wines. They can be present in wine must; can be formed by yeasts during alcoholic fermentation and by lactic acid bacteria during malolactic fermentation. They are produced by microbial, plant or animal metabolisms. Biogenic amines were detected in red wines at highest concentration. Tryptamine was a biogenic amine, which was detected in all wines at highest concentration
(170.9 \pm 5.3 ) however the most toxic biogenic amine histamine was detected only in low concentration, which varied from $0.1 \pm 0.05$ to $5.4 \pm 0.9 \mathrm{mg} / \mathrm{L}$. Biogenic amines formed in wines by yeast, but in higher concentration by lactic acid bacteria. Malolactic fermentation is very important in production of red wines and it follows that red wines contains more amount of biogenic amines that white wines. In this study were detected in wine samples the highest concentration of biogenic amine TRM, CAD and TYR.

Acknowledgements: The Paper was supported by the project: The research leading to these results has received funding from the European Community under project no 26220220180: Building Research Centre „AgroBioTech“, by grant of VEGA 1/0611/14

\section{REFERENCES}

ANCIN-AZPILICUETA, C., GONZALES-MARCO, A., JIMENEZ-MORENO N. 2008. Current knowledge about the presence of amines in wine. Critical Reviews in Food Science and Nutrition, 48, 257-275. http://dx.doi.org/10.1080/10408390701289441

ANLI, R.E., BAYRAM, M. 2008. Biogenic Amines in Wines. Food Reviews International, 25, 86-102. http://dx.doi.org/10.1080/87559120802458552

ARENA, M.E., DE NADRA, M.C.M. 2001. Biogenic amine production by Lactobacillus. Journal of Applied Microbiology, 90, 158-162. http://dx.doi.org/10.1046/j.1365-2672.2001.01223.x

BARDOCZ, S. 1995. Polyamines in food and their consequences for food quality and human health. Trends in Food Science \& Technology, 6, 341-346. http://dx.doi.org/10.1016/s0924-2244(00)89169-4

BUŇKA, F., IVIČIČOVÁ, B., BUŇKOVÁ, L., FLASAROVÁ, R., KRÁČMAR, S. 2012. Biogenic amines content in selected wines during winemaking. Journa of Microbiology Biotechnology and Food Sciences, 1, 785-793.

CAPOZZI, V., RUSSO, P., BENEDUCE, L., WEIDMANN, S., GRIECO, F., GUZZO, J., SPANO, G. 2010. Technological properties of Oenococcus oeni strains isolated from typical southern Italian wines. Letters in Applied Microbiology, 50, 327-334. http://dx.doi.org/10.1111/j.1472-765x.2010.02795.x CARUSO, M., FIORE, C., CONTURSI, M., SALZANO, G., PAPARELLA, A., ROMANO, P. 2002. Formation of biogenic amines as criteria for the selection of wine yeasts. World Journal of Microbiology and Biotechnology, 18, 159-163 http://dx.doi.org/10.1023/a:1014451728868

CHEN, H.C., KUNG, H.F., CHEN, W.C., LIN, W.F., HWANG, D.F., LEE Y.C., et al. 2008. Determination of histamine and histamine-forming bacteria in tuna dumpling implicated in a food-borne poisoning. Food Chemistry, 106, 612 618. http://dx.doi.org/10.1016/j.foodchem.2007.06.020

DADÁKOVÁ, E., KŘÍŽEK, M., PELIKÁNOVÁ, T. 2009. Determination of biogenic amines in foods using ultra-high performance liquid chromatography (UPLC). Food Chemistry, $116, \quad 365-370$ http://dx.doi.org/10.1016/j.foodchem.2009.02.018

HALÁSZ, A., BARÁTH, A., SIMON-SARKADI, L., HOLZAPFEL, W. 1994 Biogenic amines and their production by microorganisms in foods. Trends in Food Science and Technology, 5, 42-49. http://dx.doi.org/10.1016/0924 2244(94)90070-1

HALÁSZ, A., BARÁTH, A.H., HOLZAPFEL, W.H. 1999. The influence of starter culture selection on sauerkraut fermentation. European Food Research and Technology, 208, 434-438. http://dx.doi.org/10.1007/s002170050443

HERBERT, P., CABRITA, M.J., RATOLA, N., LAUREANO, O., ALVES, A 2006. Relationship between biogenic amines and free amino acid contents of wines and musts from Alentejo (Portugal). Journal of Environmental Science and Health, Part B: Pesticides, Food Contaminants, and Agricultural Wastes, 41 1171-1186. http://dx.doi.org/10.1080/03601230600856967

HERBERT, P., CABRITA, M.J., RATOLA, N., LAUREANO, O., ALVES, A., 2005. Free amino acids and biogenic amines in wines and musts from the Alentejo region. Evolution of amines during alcoholic fermentation and relationship with variety, sub-region and vintage. Journal of Food Engineering, 66, 315-322. http://dx.doi.org/10.1016/j.jfoodeng.2004.03.024

KONAKOVSKY, V., FOCKE, M., HOFFMANN-SOMMERGRUBER, K. RSCHMID, R., SCHEINER O., MOSER, P., JARISCH, R., HEMMER, W. 2011. Levels of histamine and other biogenic amines in high-quality red wines. Food Additives \& Contaminants, 28, 408-416. http://dx.doi.org/10.1080/19440049.2010.551421

KŘIZŽEK, M., PELIKÁNOVÁ, T.J. 1998. Determination of seven biogenic amines in food by micellar electrokinetic capillary chromatography. Journal of Chromatography, 815, 243-250. http://dx.doi.org/10.1016/s0021-9673(98)004646

KŘÍŽEK, M., VÁCHA, F., VORLOVÁ, L., LUKÁŠOVÁ, J., CUPÁKOVÁ, S. 2004. Biogenic amines in vacuum-packed and non-vacuum-packed flesh of carp (Cyprinus carpio) stored at different temperatures. Food Chemistry, 88, 185-191. http://dx.doi.org/10.1016/j.foodchem.2003.12.040

LANDETE, J.M., FERRER, S., PARDO, I. 2005. Which lactic acid bacteria are responsible for histamine production in wine? Journal of Applied Microbiology, 99, 580-586. http://dx.doi.org/10.1111/j.1365-2672.2005.02633.x 
LANDETE, J.M., FERRER, S., PARDO, I. 2007. Biogenic amine production by lactic acid bacteria, acetic bacteria and yeast isolated from wine. Food Control, 18, 1569-1574. http://dx.doi.org/10.1016/j.foodcont.2006.12.008

LEHANE, L. OLLEY, J. 2000. Histamine fish poisoning revisited. International Journal of Food Microbiology, 58, 1-37. http://dx.doi.org/10.1016/s01681605(00)00296-8

LONVAUD-FUNEL, A. 2001. Biogenic amines in wines: role of lactic acid bacteria. FEMS Microbiology Letters, 199, 9-13. http://dx.doi.org/10.1111/j.1574-6968.2001.tb10643.x

LOUKOU, Z., ZOTOU, A. 2003. Determination of biogenic amines as dansyl derivatives in alcoholic beverages by high-performance liquid chromatography with fluorimetric detection and characterization of the dansylated amines by liquid chromatography-atmospheric pressure chemical ionization mass spectrometry, Journal of Chromatography A, 996, 103-113. http://dx.doi.org/10.1016/s0021-9673(03)00558-2

MACROBAL, A., MARTIN-ALVAREZ, P.J., POLO, M.C., MUNOZ, R., MORENO-ARRIBAS, M.V. 2006. Formation of biogenic amines throughout the industrial manufacture of red wine. Journal of Food Protection, 69, 397-404.

MARCOBAL, A., DE LAS RIVAS, B., MORENO-ARRIBAS, M.V., MUNOZ, R. 2004. Identification of the ornithine decarboxylase gene in the putrescine producer Oenococcus oeni BIFI-83. FEMS Microbiology Letters, 239, 213-220. http://dx.doi.org/10.1016/j.femsle.2004.08.036

MARCOBAL, A., MORENO-ARRIBAS, M.V., POLO, M.C., MARTINÁLVAREZ, P.J. 2005 Biogenic amine content of red Spanish wines: comparison of a direct ELISA and an HPLC method for the determination of histamine in wines. Food Research International, 38, 387-394. http://dx.doi.org/10.1016/j.foodres.2004.10.008

MARQUES, A.P., LEITAO, M.C., ROMAO, M.V.S. 2008. Biogenic amines in wines: influence of oenological factors. Food Chemistry, 107, 853-860 http://dx.doi.org/10.1016/j.foodchem.2007.09.004

MARTIN-ALVAREZ, P.J., MACROBAL, A., POLO, C., MORENOARRIBAS, M.V. 2006. Influence of technological practices on biogenic amine contents in red wines. European Food Research and Technology, 222, 420-424. http://dx.doi.org/10.1007/s00217-005-0142-7

PENA-GALLEGO, A., HERNANDEZ-ORTE, P, CACHO, J, FERREIRA, V. 2012. High-performance liquid chromatography analysis of amines in must and wine: A review. Food Reviews International, 28, 71-96. http://dx.doi.org/10.1080/87559129.2011.594973

PIASTA, A.M., JASTRZEBSKA, A., KRZEMINSKI M.P., MUZIOL T.M., SZLYK, E. 2014. New procedure of selected biogenic amines determination in wine samples by HPLC. Analytica Chimica Acta, 834, 58-66. http://dx.doi.org/10.1016/j.aca.2014.05.028

SANTOS, M. 1996. Biogenic amines: their importance in foods. International Journal of Food Microbiology, 29, 213-231. http://dx.doi.org/10.1016/01681605(95)00032-1

SHAKILA, R.J., VASUNDHARA, T.S., KUMUDAVALLI, K.V. 2001. A comparison of the TLC densitometry and HPLC method for the determination of biogenic amines in fish and fishery products. Food Chemistry, 75, 255-259. http://dx.doi.org/10.1016/s0308-8146(01)00173-x

SHALABY, A.R. 1996. Significance of biogenic amines to food safety and human health. Food Research International, 29, 675-690. http://dx.doi.org/10.1016/s0963-9969(96)00066-x

SOUZA, S.C., THEODORO, K.H., SOUZA, E.R., DA MOTTA, S., BEATRIZ, M., GLORIA, A. 2005. Bioactive amines in Brazilian wines: types, levels and correlation with physicochemical parameters. Brazilian Archives of Biology and Technology, 48, 53-62. http://dx.doi.org/10.1590/s1516-89132005000100009

VERSARI, A., PARPINELLO, G.P., CATTANEO, M. 1999. Leuconostoc oenos and malolactic fermentation in wine: a review. Journal of Industrial $\begin{array}{llll}\text { Microbiology and Biotechnology, 23, 447-455. } & \text {. }\end{array}$ http://dx.doi.org/10.1038/sj.jim.2900733

VIDAL-CAROU, M.C., CODONY-SALCEDO, R., MARINÉ-FONT, A. 1990. Histamine and tyramine in Spanish wines: Relationships with total sulfur dioxide level, volatile acidity and malolactic fermentation intensity. Food Chemistry, 35, 217-227. http://dx.doi.org/10.1016/0308-8146(90)90035-3 